\title{
NOTES ON TENSE AND ASPECT IN THE IJESSA DIALECT OF YORUBA
}

\author{
Felix Abidemi Fabunmi \\ Obafemi Awolowo University, Ile-Ife, Nigeria
}

Ijeșa is a dialect of Yoruba in which there are three aspect markings-progressive, habitual, and perfective-and one tense marking-future. Tense/aspect marking in the Ijẹsa dialect differs from that found in Standard Yoruba. Consider first aspectual marking. The progressive in Ijẹsa is marked by mí rather than the ń of Standard Yoruba, as shown in (1).

(1) Ijẹ̦a

a. Mo mí loọ́ roko. 1

I PROG go farm

'I am going to the farm.'

b. Adé mí jẹn.

'Ade is eating.'

c. Mọ ti mí susé.

I PF PROG do_work

'I have been working.'
Standard Yoruba

Mo ń

lọ sí roko.

to

In imperative constructions, such as those shown in (2), Ijẹsa allows either the bare verb (2a) or progressive marker $a$ plus verb (2b-c). Standard Yoruba, on the other hand, requires the auxiliary máa and does not permit use of either the bare verb or the progressive form. Ijẹsa $a$ is a reduced form of máa, which no longer occurs as a progressive marker in this form in Ijessa.

The habitual is marked by a vowel that assimilates to the preceding vowel in Ijẹsa, but by máa ń in Standard Yoruba, as in (3).

1 Abbreviations are as follows:

$\mathrm{HAB}$ habitual

FUT future

PF perfect

PROG progressive 
(2) Ijẹ̦a

a. $B O$ 'come'

b. $A$ bọ̀.

PROG come

'Come.'

Ijẹșa

c. $A$

PROG eat

'Eat.'

(3) Ijẹsa

a. Bọlá á tù wé.

Bola HAB sell book

'Bola is always selling books.'

b. É é á.

he $\mathrm{HAB}$ come

'He always comes here.'

c. Ơîtọ́ nùkàn lé $\quad$ é $\quad$ sọ. truth only is_he HAB speak

'He speaks only the truth.'
Standard Yoruba

*bọ

Máa bọ̀.

be come

'Come.'

cf. $A b \grave{o}$.

we come

'We arrived.'

Standard Yoruba

Máa jẹun. cf. A jẹun.
be eat

'Eat.'

Standard Yoruba

Bọlá máa ń ta ìwé.

$\mathrm{HAB}$ sell

Á máa ń wá.

he HAB come

Ộtítọ nìkan ni ó máa ń sọ. is he $\mathrm{HAB}$

Future tense marking also differs in the two dialects. In Ijẹsa, it is marked by either $a$ or $a$, in contrast to the variant forms yóò, yó, ó, or máa in Standard Yoruba.

(4) Ijẹsa

a. Mà a ga.

I FUT tall

'I will become tall.'

b. Supọá lọ.

Supo FUT go

'Supo will go.'
Standard Yoruba

Olú yóòyóló sọ̀rọ.

Olu FUT talk

'Olu will talk.'

Olú máa sọ̀ọ̀.

Olu FUT taik

'Olu will talk.' 